\title{
IMPLEMENTASI MODEL PEMBELAJARAN TUTOR SEBAYA DALAM PENINGKATAN HASIL BELAJAR PADA MATERI PECAHAN DI KELAS IV SDN 105400 MAROMBUN UJUNG JAWI
}

\author{
Usrek Sarwini \\ Guru SDN 105400 Marombun Ujung Jawi \\ Surel : Rizkiandriani21@yahoo.com
}

\begin{abstract}
ABSTRAK
Penelitian ini bertujuan untuk meningkatkan keterampilan berpidato siswa melalui model pembelajaran tutor sebaya. Jenis penelitian adalah penelitian tindakan kelas. Awal KBM dilakukan tes hasil belajar dengan rata-rata 28,6 hal tersebut menunjukkan siswa tidak belajar di rumah sebelum memulai pembelajaran di sekolah. Kemudian dilanjutkan KBM, diakhir siklus I dan siklus II dilakukan tes belajar sebagai formatif I dan formatif II. Nilai formatif I yaitu sebesar 14,28\% dengan rata - rata 60,0 dan belum tuntas secara klasikal. Data nilai formatif II sebesar 85,7 \% dengan rata-rata 77,1 menunjukkan tuntas secara individu dan kelas. Terjadi peningkatan hasil belajar siswa dengan menerapkan model pembelajaran tutor sebaya.
\end{abstract}

Kata kunci: Model Tutor Sebaya, Hasil belajar

\section{PENDAHULUAN}

Era globalisasi yang penuh dengan kompetitif merupakan tantangan bagi dunia pendidikan. Teknologi pembelajaran inovatif seyogyanya dikembangkan dengan cara mengadaptasi atau mengadopsi teknologi pembelajaran inovatif yang memenuhi standar internasional. Hal ini tidak lain merupakan salah satu upaya untuk memenuhi amanat salah satu kebijakan inovatif, yaitu mutu lulusan tidak cukup bila diukur dengan standar lokal atau nasional saja. (Mohamad Nur, 2003).

Pembelajaran Matematika tidak lagi mengutamakan pada penyerapan melalui pencapaian informasi, tetapi lebih mengutamakan pada pengembangan kemampuan dan pemrosesan informasi. Untuk itu aktivitas peserta didik perlu ditingkatkan melalui latihan-latihan atau tugas matematika dengan bekerja kelompok kecil dan menjelaskan ide - ide kepada orang lain (Hartoyo, 2000:24). Dalam pembelajaran matematika agar mudah dimengerti oleh siswa, proses penalaran deduktif untuk menguatkan pemahaman yang sudah dimiliki oleh siswa. Tujuan pembelajaran matematika adalah melatih cara berfikir secara sistematis, logis, kritis, kreatif dan konsisten.

Langkah - langkah tersebut memerlukan partisipasi aktif dari siswa. Untuk itu perlu ada model pembelajaran yang melibatkan siswa 
secara langsung dalam pembelajaran.

Pembelajaran kooperatif adalah strategi belajar dimana peserta didik dibuat dalam kelomopok - kelompok kecil. Salah satu model pembelajaran kooperatif adalah tutor sebaya. Ada kalanya seorang siswa lebih mudah menerima keterangan yang diberikan oleh teman sebaya atau temantemannya yang lain. Sumber belajar seperti ini yang disebut dengan tutor sebaya, karena mereka mempunyai usia yang hampir sebaya atau sama.

Tutor sebaya adalah sumber belajar selain guru yaitu teman sebaya yang lebih pandai memberikan bantuan belajar kepada teman-teman sekelasnya di sekolah. Bantuan belajar oleh teman sebaya dapat menghilangkan kecanggungan, lebih mudah dipahami, tidak ada rasa enggan, rendah diri, malu dan sebagainya untuk bertanya ataupun minta bantuan.

Rendahnya motivasi siswa terhadap pelajaran matematika mengakibatkan rasa ingin tahu berkurang, serta monoton dalam proses pembelajaran yang hanya menggunakan metode ceramah. Begitu juga dengan siswa kelas IV SDN 105400 Marombun Ujung Jawi.

Sebagai pengajar di sekolah tersebut ketika kegiatan belajar mengajar berlangsung siswa selalu fasif. Masih kedapatan siswa yang mengobrol, dan tidur. Sehingga hasil ulangan rendah terhadap operasi hitung pecahan.mendapakan nilai rendah dibawah KK, sehingga perluh perhatian kepada siswa dengan seperti pembelajaran kooperatif. melakukan upaya untuk mengoptimalkan pembelajaran agar peserta didik berpean aktif.

Untuk mengatasi masalah tersebut akan diuji cobakan pembelajaran tutor sebaya. Penggunaan model pembelajaran tutor sebaya salah satu alternative untuk meningkatkan hasil belajar. Dengan menerapkan model ini siswa memiliki peluang untuk bertanya kepada teman yang dianggapnya dapat membimbingnya. Sehingga siswa bebas bertanya tentang hal yag tidak atau kurang diketahuinya. Guru mengambil materi operasi belingan pecahan karena sebagian besar masih kebingungan dalam menyelasaikan operasi bilangan pecahan.

Berdasarkan latar belakang diatas yang telah diuraikan diatas, dapat diindentifikasi masalahnya yaitu: (1) metode pembelajaran kurang bervariasi, (2) sering terjadi kegiatan yang tidak sesuai dengan kegiatan belajar mengajar (KBM) di dalam kelas, seperti siswa ribut, siswa mengantuk dan lain sebagainya. (3) Guru tidak menggunakan media dalam mengajar sehingga siswa sulit memahami materi yang diajarkan. Berdasarkan indentifikasi masalah ini, rumusan masalah ini adalah (1) Bagaimana hasil belajar siswa yang diajar dengan menggunakan model pembelajaran tutor sebaya di kelas IV SDN 105400 Marombun Ujung Jawi?, (2) Bagaimana aktivitas belajar siswa dengan diterapkannya model pembelajaran tutor sebaya 
selama KBM di kelas IV SDN 105400 Marombun Ujung Jawi?

Adapun tujuan penelitian yang ingin dicapai adalah (1) untuk mengetahui bagaimana peningkatan hasil belajar siswa yang diajar dengan menggunakan model pembelajaran tutor sebaya di kelas IV SDN 105400 Marombun Ujung Jawi, (2) untuk mengetahui bagaimana aktivitas belajar siswa dengan diterapkannya model pembelajaran tutor sebaya di kelas IV SDN 105400 Marombun Ujung Jawi.

\section{METODE PENELITIAN}

Penelitian ini akan dilaksanakan SDN 105400

Marombun Ujung Jawi Kecamatan Bangun Purba yang beralamat di Desa Marombun Ujung Jawi Kecamatan Bangun Purba. Penelitian ini dilaksanakan pada semester genap selama 5 (bulan) bulan mulai dari bulan Maret sampai dengan Juli 2015. Subjek penelitian ini adalah siswakelas IV 105400 Marombun Ujung Jawi yang berjumlah 7 siswa. Penelitian ini berbentuk Penelitian Tindakan Kelas (PTK). Penelitian tindakan kelas adalah penelitian yang dilakukan oleh guru di kelas atau di sekolah dengan penekanan pada penyempurnaan atau peningkatan proses pembelajaran. Dalam satu siklus terdiri atas empat langkah yaitu: perencanaan (planning) tindakan (acting), observasi (observing) dan refleksi (reflecting).

\section{HASIL PENELITIAN DAN PEMBAHASAN \\ Hasil Penelitian}

Data hasil Pretes menunjukkan nilai terendah untuk Pretes adalah 2 dan tertinggi adalah 50 dengan KKM (kriteria ketuntasan minimum) sebesar 65 maka tidak seorang pun mendapat nilai diatas ketuntasan atau ketuntasan klasikal adalah 0\%. Nilai rata - rata kelas adalah 28,6 yang juga tidak tuntas. Dari data tersebut dapat disimpulkan bahwa siswa tidak belajar di rumah.

\section{Siklus I}

Setelah berakhirnya pelaksanaan siklus I diadakan tes hasil belajar kognitif yang selanjutnya disebut sebagai formatif I. Hasil belajar kognitif yang diperoleh pada siklus I selama dua pertemuan disajikan dalam Tabel 1 .

Tabel Distribusi Hasil Formatif I

\begin{tabular}{|c|c|c|}
\hline Nilai & Frekuensi & Rata-rata \\
\cline { 1 - 2 } 40 & 1 & \multirow{2}{*}{60,0} \\
\cline { 1 - 2 } 60 & 5 & \multirow{2}{*}{60} \\
\hline 80 & 1 & \\
\cline { 1 - 2 } Jumlah & 7 & \\
\hline
\end{tabular}

Merujuk Tabel 1, nilai terendah formatif I adalah 40 dan tertinggi adalah 80. Merujuk pada KKM sebesar 65 maka hanya 1 dari 7 orang siswa mendapat nilai ketuntasan atau ketuntasan klasikal tercapai sebesar $14,28 \%$. Nilai ini berada di bawah kriteria ketuntasan klasikal sebesar $85 \%$ sehingga dapat dikatakan KBM siklus I gagal memberi ketuntasan belajar dalam 
kelas. Nilai rata-rata kelas adalah 60,0 masih di bawah KKM. Dengan demikian maka peneliti berusaha melakukan tindakan perbaikan dalam melaksanakan pembelajaran siklus II yang dirasa perlu. Kemudian penilaian aktivitas diperoleh dari lembar observasi aktivitas dilakukan pada saat siswa bekerja dalam kelompok diskusi. Pengamatan dilakukan oleh dua pengamat selama 20 menit kerja kelompok dalam setiap kegiatan belajar mengajar (KBM). Hasil observasi aktivitas siswa disajikan dalam Tabel 2.

Tabel Skor Aktivitas Belajar Siswa Siklus I

\begin{tabular}{|c|l|c|c|}
\hline No & \multicolumn{1}{|c|}{ Aktivitas } & Skor & Persentase \\
\hline 1 & $\begin{array}{l}\text { Menulis dan } \\
\text { Membaca }\end{array}$ & 7 & $40 \%$ \\
\hline 3 & $\begin{array}{l}\text { Mengerjakan } \\
\text { LKS }\end{array}$ & 3,75 & $21 \%$ \\
\hline 4 & $\begin{array}{l}\text { Bertanya pada } \\
\text { teman } \\
\text { Pertanyaan } \\
\text { Teman }\end{array}$ & 1,25 & $7 \%$ \\
\hline 5 & $\begin{array}{l}\text { Bertanya pada } \\
\text { guru }\end{array}$ & 2,75 & $15 \%$ \\
\hline 6 & $\begin{array}{l}\text { Yang tidak } \\
\text { relevan }\end{array}$ & 2 & $11 \%$ \\
\hline \multicolumn{2}{|l|}{ Jumlah } & 17,5 & $100 \%$ \\
\hline
\end{tabular}

\section{Siklus II}

Diakhir siklus II diberikan tes hasil belajar sebagai formatif II dengan jumlah soal 5 item. Data formatif II disajikankan dalam Tabel 3.
Tabel Distribusi Hasil Formatif II

\begin{tabular}{|c|c|c|}
\hline Nilai & Frekuensi & Rata-rata \\
\hline 60 & 1 & \multirow{2}{*}{77,1} \\
\cline { 1 - 2 } 80 & 6 & \multirow{2}{*}{70} \\
\cline { 1 - 2 } Jumlah & 7 & \\
\hline
\end{tabular}

Merujuk pada Tabel 3, nilai terendah untuk formatif II adalah 60 dan tertinggi adalah 80 dengan 6 orang siswa mendapat nilai dibawah KKM atau ketuntasan klasikal adalah sebesar $85,7 \%$. Nilai ini berada di atas $85 \%$ sehingga dapat dikatakan KBM siklus II telah berhasil memberi ketuntasan belajar pada siswa dalam kelas. Nilai rata-rata kelas adalah 77,1 dan telah memenuhi KKM.

Aktivitas siswa pada siklus II mengalami peningkatan dibandingkan siklus I. Hasil pengamatan aktivitas belajar siswa pada siklus II disajikan pada tabel 4.3 .

Tabel Skor Aktivitas Belajar Siswa Siklus II

\begin{tabular}{|l|l|c|c|}
\hline No & Aktivitas dan & Skor & Persentase \\
\hline 1 & $\begin{array}{l}\text { Menulis } \\
\text { Membaca }\end{array}$ & 4,5 & $25,7 \%$ \\
\hline 2 & $\begin{array}{l}\text { Mengerjakan } \\
\text { LKS }\end{array}$ & 7 & $40 \%$ \\
\hline 3 & $\begin{array}{l}\text { Bertanya pada } \\
\text { teman }\end{array}$ & 2,5 & $14,3 \%$ \\
\hline 4 & $\begin{array}{l}\text { Menjawab } \\
\text { Pertanyaan Guru }\end{array}$ & 2,5 & $14,3 \%$ \\
\hline 5 & $\begin{array}{l}\text { Bertanya pada } \\
\text { guru }\end{array}$ & 0,5 & $2,9 \%$ \\
\hline 6 & $\begin{array}{l}\text { Yang tidak } \\
\text { relevan }\end{array}$ & 17,5 & $100 \%$ \\
\hline Jumlah
\end{tabular}


Dilihat table 3. Memiliki peningkatan hasil belajar sehinggan model pembelajaran tutor sebaya telah berhasil meningakatkan hasil belajar siswa pada materi pecahan.

\section{Pembahasan}

Hasil belajar pada siklus I diperoleh nilai rata-rata 60,0 dengan ketuntasan belajar yang dicapai $14,28 \%$, karena kurang dari $85 \%$ siklus I dikatakan tidak tuntas. Setelah dilakukan perbaikan pembelajaran pada siklus II diperoleh rata - rata hasil belajar sebesar 77,1 dengan ketuntasan klasikal mencapai 85,7\%, karena lebih besar dari $85 \%$ maka siklus II dikatakan berhasil memberikan ketuntasan belajar klasikal.

Berdasarkan hasil belajar kognitif dan pengamatan siklus I menunjukkan bahwa masih terdapat beberapa permasalahan/kekurangan dalam pelaksanaan tindakan yang perlu diperbaiki secara lanjut. Beberapa kelemahan pada siklus I terlihat dari aktivitas siswa dalam mengikuti pembelajaran, diantaranya:

1. Efektivitas Kelompok

a) Kemampuan tutor sebaya dalam kelompoknya masih kurang.

b) Kekompakan kerja kelompoknya masih kurang.

c) Anggota kelompok masih enggan dan malu bertanya pada temannya (tutor).

d) Masih ada siswa yang tidak mau tau dan menyerahkan permasalahan pada tutor dan teman 1 kelompoknya.

2. Aktivitas siswa dalam mengikuti pembelajaran

a) Suasana pembelajaran kurang kondusif.

b) Dalam mengerjakan tugas di depan kelas siswa kurang berani terlihat dari siswa saling menyuruh satu sama lain.

c) Suasana diskusi antar siswa masih kurang. Masih banyak siswa yang mencoba mengerjakan LKS secara individual dan tidak bertanya pada tutor jika ada hal yang mereka tidak mengerti.

d) Tutor sebaya dalam memimpin kelompoknya masih kurang.

Kemudian aktivitas belajar dari lembar obervasi dalam proses pembelajaran ini setiap siswa dilibatkan secara keseluruhan oleh guru. Para siswa harus memperhatikan guru saat memberikan penjelasan. Selain itu guru juga berkeliling memantau dan memberikan bimbingan kepada siswa yang mengalami kesulitan dalam menangkap inti. Pelajaran serta yang mengalami kesulitan dalam mengerjakan soal. Setelah berdiskusi guru juga mengunjuk perwakilan setiap kelompok untuk mengerjakan kembali soal secara lisan di depan kelas. Hal ini dilakukan untuk mengevaluasi pemahaman siswa terhadap pembelajaran. 
Perbandingan aktivitas antara siklus I dan siklus II dijabarkan sebagai berikut: aktivitas menulis dan membaca turun dari $40 \%$ menjadi $25,7 \%$. Hal ini cukup memuaskan peneliti karena penurunan aktivitas membaca mengindikasikan bahwa siswa telah mempersiapkan diri dari rumah sebelum mengikuti pembelajaran di kelas. Aktivitas mengerjakan dalam diskusi yang meningkat dari $21 \%$ menjadi $40 \%$ menunjukkan perbaikan yang terjadi dalam proses pembelajaran di mana siswa lebih aktif dalam pelaksanaan diskusi. Sementara aktivitas bertanya pada teman naik dari $7 \%$ menjadi $14,3 \%$, hal ini mengindikasikan bahwa siswa telah lebih mandiri dalam berpikir dan lebih koperatif sehingga siswa tidak enggan bertanya pada tutor. Aktivitas menjawab pertanyaan teman meningkat dari $4 \%$ menjadi $14,3 \%$ hal ini di pengaruhi oleh aktivitas bertanya, dan mengindikasikan peningkatan koperatif serta kemampuan tutor untuk membimbing teman satu kelompoknya. Aktivitas bertanya pada guru turun dari $15 \%$ menjadi 2,9\%. Hal ini dikarenakan peningkatan daya pikir siswa dan koperatif siswa, sehingga ketergantungan siswa terhadap guru mengalami penurunan. Aktivitas yang tidak relevan dengan KBM turun dari $11 \%$ menjadi $3 \%$ yang menandakan perbaikan aktivitas belajar siswa.

Dengan demikian pembelajaran menggunakan model tutor sebaya memberikan ketuntasan belajar Matematika siswa pada siklus II. Pembelajaran tutor sebaya selain meningkatkan hasil belajar siswa ternyata juga telah mampu menumbuhkan sikap koperatif disamping tumbuhnya minat belajar siswa terhadap pembelajaran Matematika yang berimplikasi pada meningkatnya aktivitas dan hasil belajar siswa.

\section{KESIMPULAN}

Hasil analisis tersebut dapat disimpulkan sesuai dengan rumusan masalah, yaitu :

1. Hasil belajar siswa dengan menggunakan model pembelajaran tutor sebaya mengalami peningkatan. Pada siklus I ketuntasan sebesar 14,28 $\%$ dengan rata-rata 60,0 dan belum tuntas secara klasikal dan pada siklus II sebesar 85,7 \% dengan rata-rata 77,1 menunjukkan tuntas secara individu dan kelas.

2. (a) Data aktivitas siswa menurut pengamatan pengamat pada siklus I antara lain membaca/menulis (40\%), bekerja $(21 \%)$, bertanya sesama teman (7\%), menjawab pertanyaan teman (4\%), bertanya kepada guru (15\%), dan yang tidak relevan dengan KBM (11\%).

(b) Data aktivitas siswa menurut pengamatan pada Siklus II antara lain membaca/menulis $(25,7 \%)$, bekerja $(40 \%)$, bertanya sesama teman $(14,3 \%)$, menjawab pertanyaan teman (14,3), 
bertanya kepada guru (2,9\%), dan yang tidak relevan dengan KBM (3\%).

\section{DAFTAR RUJUKAN}

Arikunto, Suharsimi. 2002. Dasar Dasar Evaluasi Pendidikan. Jakarta: Bumi Aksara.

Arikunto, Suharsimi. 2002. Prosedur Penelitian Suatu

Pendekatan Praktek.
Degeng, I N. S. 1988. Ilmu Pengajaran: Taksonomi Variabel. Jakarta: Depdikbud Dirjen Dikti P2LPTK.

Zaini, Hisyam.dkk. 2008. Strategi Pembelajaran Aktif. Yogyakarta: Pustaka Insan Madani

Aqib. Zainal. 2011. Penelitian Tindakan Kelas. Bandung: Yrama Widya. 